\title{
PENINGKATAN PROMOSI KESEHATAN MELALUI EDUKASI PENCEGAHAN PENYAKIT DEMAM BERDARAH
}

\author{
Enny Irawaty, ${ }^{1}$ Winnie Arnissa Chen, ${ }^{2}$ Gabriela Miracle ${ }^{3}$ \\ ${ }^{1}$ Bagian Fisiologi , Fakultas Kedokteran, Universitas Tarumanagara Jakarta \\ Email: ennyi@fk.untar.ac.id \\ ${ }^{2}$ Mahasiswa Fakultas Kedokteran Universitas Tarumanagara Jakarta \\ Email: winnie.405190063@stu.untar.ac.id \\ ${ }^{3}$ Mahasiswa Fakultas Kedokteran Universitas Tarumanagara Jakarta \\ Email: gabriela.405190064@stu.untar.ac.id
}

\begin{abstract}
Efforts to control the increase in cases of dengue hemorrhagic fever, especially in endemic areas, need to be improved and collaboration with the community is needed. The problem faced by the community due to the spread of dengue hemorrhagic fever is the incompatibility of knowledge and community actions in efforts to eradicate mosquito nests in daily life, there is still low public awareness to apply the good habits in preventing cases of dengue hemorrhagic fever. Based on the problems described, the service team carried out a promotive activity to increase awareness of the importance of implementing appropriate dengue hemorrhagic fever prevention in daily life and $3 M$ plus preventive measures in the spread of dengue fever cases through community independence. The health education activity organized by the FK UNTAR service team with the theme "Prevent Dengue Fever" starting from 13.00-14.00 was attended by 34 participants who have registered and act as the dengue hemorrhagic fever prevention team in the Tomang area of West Jakarta. Participants took part in educational activities delivered by the service team until they were finished. The participants' initial test results obtained an average score of 67.65 and for the post-test results, the average score of participants was 84.56 . It can be seen that there is an increase in knowledge of dengue hemorrhagic fever prevention by $25 \%$. The pre-test scores showed that the participants had fairly good knowledge regarding prevention, and after health education by the service team, the level of knowledge of the participants was getting better.
\end{abstract}

Keywords: prevention, dengue hemorrhagic fever, $3 M$ Plus

\begin{abstract}
ABSTRAK
Upaya pengendalian peningkatan kasus demam berdarah dengue terutama pada daerah endemik perlu ditingkatkan dan perlu kerjasama dengan masyarakat. Masalah yang dihadapi pada masyarakat karena kasus penyebaran demam berdarah dengue yaitu tidak sejalannya pengetahuan dan tindakan masyarakat dalam upaya pemberantasan sarang nyamuk dalam kehidupan sehari-hari, masih rendahnya kesadaran masyarakat untuk menerapkan kebiasaan yang tepat dalam pencegahan kasus demam berdarah dengue. Berdasarkan permasalahan yang diuraikan maka tim pengabdian melakukan suatu kegiatan promotif dalam upaya meningkatkan kesadaran pentingnya penerapan pencegahan demam berdarah dengue yang tepat di kehidupan sehari-hari serta tindakan preventif $3 \mathrm{M}$ plus dalam penyebaran kasus demam berdarah melalui kemandirian masyarakat. Kegiatan edukasi kesehatan yang diselenggarakan tim pengabdian FK UNTAR dengan tema "Cegah Demam Berdarah" dimulai 13.00-14.00 telah diikuti 34 peserta yang sudah terdaftar dan berperan sebagai tim pencegahan demam berdarah dengue di wilayah Tomang Jakarta Barat. Peserta mengikuti kegiatan edukasi yang disampaikan tim pengabdian sampai selesai. Hasil pre-test para peserta didapatkan nilai rata-rata sebesar 67,65 dan untuk hasil post-test didapatkan nilai rata-rata peserta 84,56 . Berdasarkan hasil dari nilai rata-rata pre-test ke nilai rata-rata post-test, dapat dilihat terjadi peningkatan pengetahuan pencegahan demam berdarah dengue sebesar $25 \%$. Hasil nilai pretest para peserta menunjukkan peserta mempunyai pengetahuan yang cukup baik terkait pencegahan, dan setelah mendengarkan materi yang disampaikan tim pengabdian, tingkat pengetahuan peserta semakin baik.
\end{abstract}

Kata kunci: pencegahan, demam berdarah dengue, 3M Plus

\section{PENDAHULUAN}

Seiring perjalanan waktu angka kejadian kasus orang yang terkena demam berdarah dengue mengalami penurunan, tetapi di Indonesia kasus penderita demam berdarah masih menjadi penyebab masalah kesehatan yang dapat berakibat kematian apabila penanganan demam 
berdarah kurang adekuat. Prevalensi kasus demam berdarah dengue pada tahun 2017 ditemukan sebanyak 68.407 penderita dan kasus kematian akibat demam berdarah dengue sebanyak 493 kasus (Kemenkes RI, 2018). Prevalensi kejadian demam berdarah dengue yang dilaporkan pada awal bulan Juli 2020 ditemukan sebanyak 71.633 kasus. Wilayah dengan kasus demam berdarah dengue tertinggi di Indonesia yaitu Jawa Barat dengan jumlah 10.772 kasus, lalu Bali berada di urutan kedua sebanyak 8.930 kasus. DKI Jakarta sendiri menempati posisi keenam dari 10 provinsi di Indonesia dengan tingkat kasus terbanyak ( Kemenkes,2021).

Endemisitas demam berdarah dengue dipengaruhi tiga faktor yaitu yaitu host (manusia), vektor (Aedes aegypti dan Aedes albopictus) serta lingkungan. Kasus meningkatnya kejadian demam berdarah dengue berhubungan langsung dengan masyarakat dan lingkungan, sehingga memungkinkan penyebaran penularan yang semakin luas. Peningkatan penyebaran demam berdarah dengue sejalan dengan peningkatan mobilitas serta kepadatan penduduk di wilayah endemis (Husni, 2018).

Faktor yang mempengaruhi penyebaran demam berdarah dengue ditentukan oleh beberapa hal yaitu demografi penduduk, lingkungan seperti suhu lingkungan, kelembaban lingkungan berpengaruh pada aktivitas nyamuk Aedes aegypti dalam bereproduksi serta nenularkan virus dengue ke host (Karyanti, 2009). Tren penyebaran penyakit demam berdarah dengue di Indonesia dari tahun ke tahun fluktuatif sehingga perlu adanya upaya pengendalian kasus demam berdarah dengue. Demam berdarah dengue dapat mengakibatkan kematian apabila tanpa penanganan yang tepat atau terlambat pengobatannya. Upaya pengendalian peningkatan kasus demam berdarah dengue terutama pada daerah endemik atau rawan sangat perlu ditingkatkan dan perlu kerjasama dengan masyarakat (Kemenkes RI, 2017).

Pencegahan penyebaran penyakit yang tepat serta cepat sangat dibutuhkan di daerah yang memiliki transmisi tinggi. Masalah yang dihadapi pada masyarakat karena kasus penyebaran demam berdarah dengue yaitu tidak sejalannya pengetahuan dan tindakan masyarakat dalam upaya pemberantasan sarang nyamuk dalam kehidupan sehari-hari. Masyarakat sudah mempunyai pengetahuan cara mencegah demam berdarah dengue tetapi penerapannya tidak sesuai. Kondisi ini menunjukkan masih rendahnya kesadaran masyarakat untuk menerapkan kebiasaan yang tepat dalam pencegahan kasus demam berdarah dengue. Berdasarkan permasalahan yang diuraikan maka tim pengabdian melakukan suatu kegiatan promotif dalam upaya meningkatkan kesadaran pentingnya penerapan pencegahan demam berdarah dengue yang tepat di kehidupan sehari-hari serta tindakan preventif $3 \mathrm{M}$ plus dalam penyebaran kasus demam berdarah melalui kemandirian masyarakat.

\section{METODE PELAKSANAAN PKM}

Tim pengabdian masyarakat melakukan persiapan untuk kegiatan pengabdian yaitu identifikasi permasalahan yang dihadapi terkait demam berdarah terutama masa pandemi. Tim pengabdian mengadakan rapat persiapan yaitu meninjau metode kegiatan pengabdian, menyiapkan materi kegiatan terkait demam berdarah dengue dan mengajukan proposal untuk kegiatan pengabdian masyarakat. Pelaksanan kegiatan bakti kesehatan disetujui hari Sabtu, tanggal 2 Oktober 2021 pukul 13.00-14.00. Kegiatan edukasi penyuluhan pencegahan DBD dilakukan secara daring dengan aplikasi zoom meeting karena masih terkendala PPKM. Pengukuran dampak penyuluhan dilakukan secara kuantitatif yaitu apabila pertanyaan berupa pre-test dan post-test yang diberikan oleh penyuluh dapat dijawab dengan benar oleh pasien, menunjukkan penyampain materi yang diberikan dapat diterima oleh peserta. Evaluasi secara kualitatif di akhir penyuluhan berupa pertanyaan langsung yang disampaikan secara lisan kepada peserta, diantaranya peserta diminta untuk menyebutkan pencegahan demam berdarah dengue dan $3 \mathrm{M}$ plus. Tim pengabdian membuat kuesioner untuk menilai pengetahuan awal terkait pencegahan 
demam berdarah berupa pre-test dan menilai apakah kegiatan edukasi ini memberikan manfaat bagi mitra berupa post-test, sehingga kegiatan ini dapat berlangsung berkelanjutan dan berkesinambungan. Target kegiatan jangka pendek menambah wawasan serta kesadaran pada masyarakat pencegahan demam berdarah terutama pada masa pandemi. Manfaat kegiatan adalah mitra bertambah wawasan kesehatan terkait pencegahan demam berdarah. Target jangka menengah adalah mitra dapat meningkatkan derajat kesehatan serta kualitas hidup dalam pencegahan akibat penyakit demam berdarah. Target jangka panjang adalah menurunkan angka kematian akibat demam berdarah serta menyukseskan program 3M plus dalam pencegahan demam berdarah dengue.

\section{HASIL DAN PEMBAHASAN}

Penyuluhan kegiatan pengabdian dilakukan dengan sistem daring via zoom karena terkendala PPKM sehingga tim pengabdian tidak bisa bertatap muka dengan peserta. Tim pengabdian melakukan survei awal terkait demam dengue dan didapatkan hasil masih banyak warga Tomang belum menerapkan kesadaran dalam pencegahan demam berdarah dengue seperti pakaian digantung sembarangan, menjelang musim hujan mereka takut banyak nyamuk demam berdarah serta terkendala pandemi maka kegiatan kader jumantik juga terbatas untuk turun ke warga Tomang.

Tim pengabdian pada persiapan kegiatan menetapkan materi pengabdian yaitu cegah demam berdarah. Sasaran dari kegiatan adalah kader Tomang Jakarta Barat terutama yang berperan pada pencegahan kasus demam berdarah di wilayah Tomang Jakarta Barat. Tim Pengabdian berkoordinasi dengan perwakilan kader dengan membagikan flyer agar peserta pengabdian melakukan pendaftaran melalui link formular pendaftaran yang tertera di flyer. Penyebaran flyer dilakukan 1 minggu sebelum kegiatan serta peserta yang sudah terdaftar nantinya akan diberikan link zoom kegiatan pengabdian. Menjelang acara kegiatan maka tim berkoordinasi secara internal membahas persiapan materi, kuesioner yang dibagikan sebelum dan sesudah penyampaian materi serta mengecek apakah ada peserta yang terkendala dengan aplikasi zoom.

Kegiatan edukasi kesehatan yang diselenggarakan tim pengabdian FK UNTAR dengan tema "Cegah Demam Berdarah" pada pukul 13.00-14.00, telah diikuti 34 peserta yang sudah terdaftar dan berperan sebagai kader dalam pencegahan demam berdarah di wilayah Tomang Jakarta Barat. Tim pengabdian memulai membuka zoom pada pukul 12.30 dan sekitar pukul 12.45 WIB para peserta kegiatan yang sudah terdaftar dipersilahkan masuk ke dalam ruang pertemuan zoom. Pada pembukaan tim pengabdian menyapa peserta dan berterima kasih sudah mau berpartisipasi menyukseskan kegiatan penyuluhan. Tim pengabdian meminta peserta mengisi pre-test terkait materi pencegahan penyakit demam dengue. 


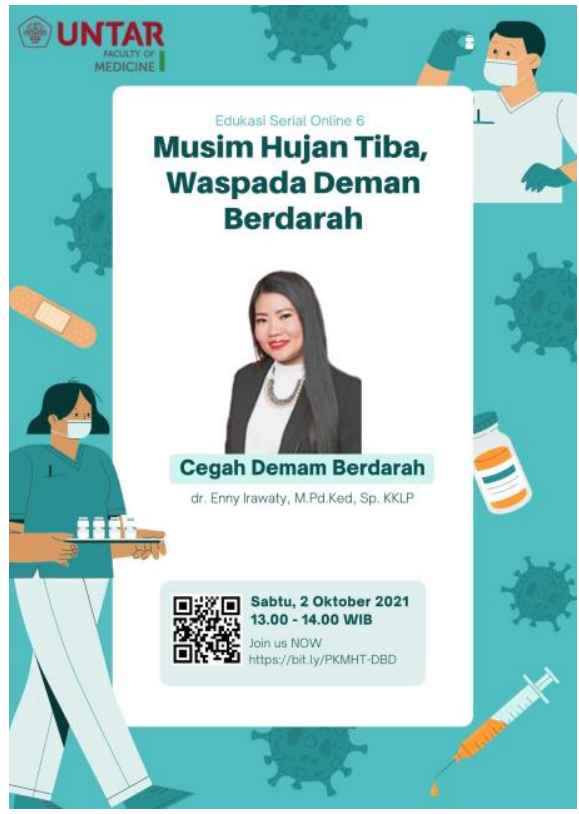

Gambar 1. Flyer Kegiatan

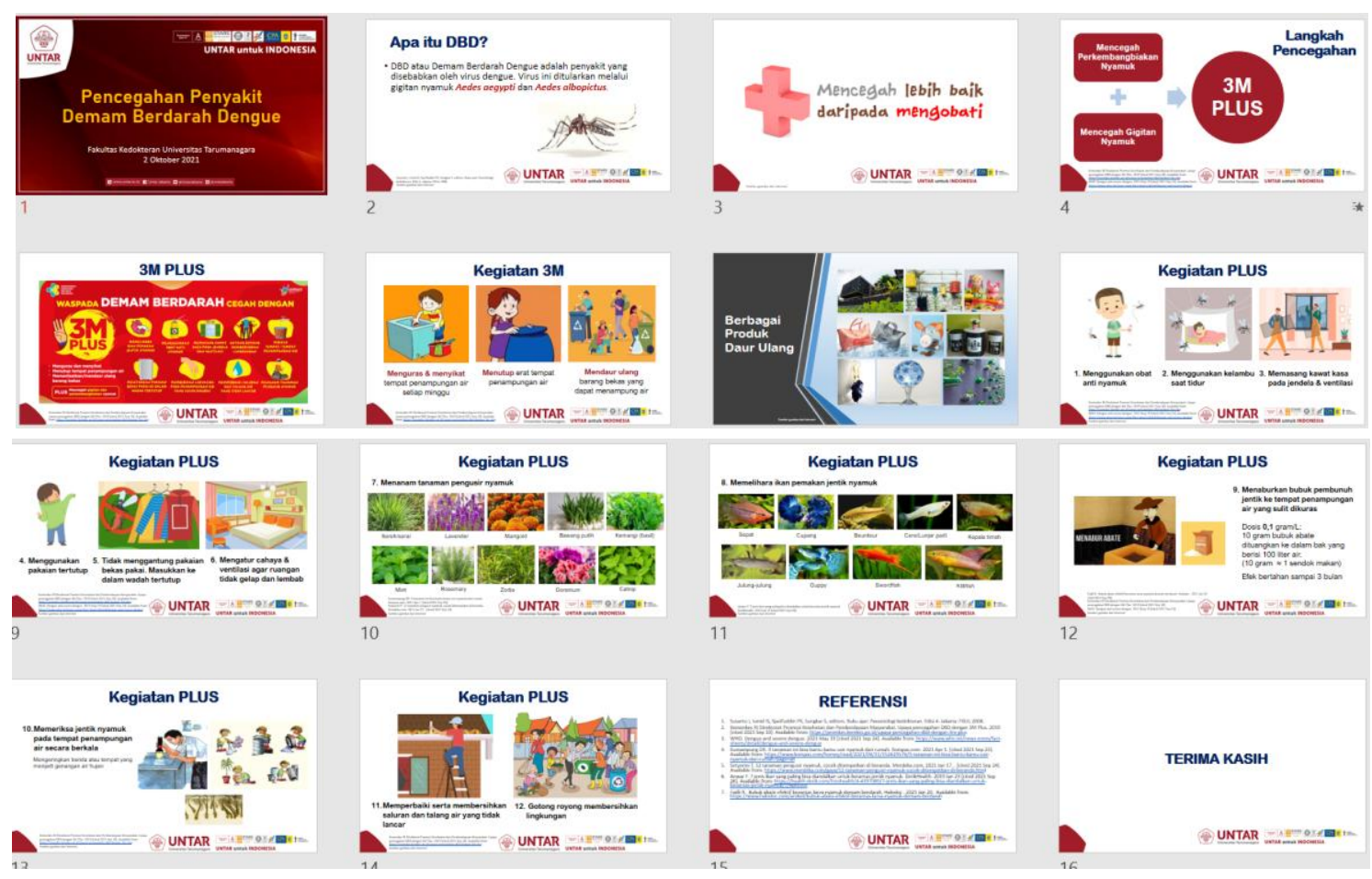

Gambar 2. Materi Kegiatan

Tujuan diadakan kegiatan pengabdian adalah meningkatkan kesadaran peserta dalam upaya pencegahan demam berdarah yang dapat diterapkan secara benar dalam kehidupan sehari-hari. Peserta pengabdian diterangkan oleh tim pengabdian tentang apa itu demam berdarah dengue, virus penyebabnya serta cara penularan. Tim pengabdian menyampaikan langkah pencegahan demam berdarah dengue serta $3 \mathrm{M}$ plus. Materi $3 \mathrm{M}$ plus disampaikan dengan gambar yang disertai keterangan agar kader jelas dengan kegiatan $3 \mathrm{M}$ plus. Tim juga mengingatkan ke peserta bahwa pencegahan demam berdarah lebih baik daripada mengobati. 

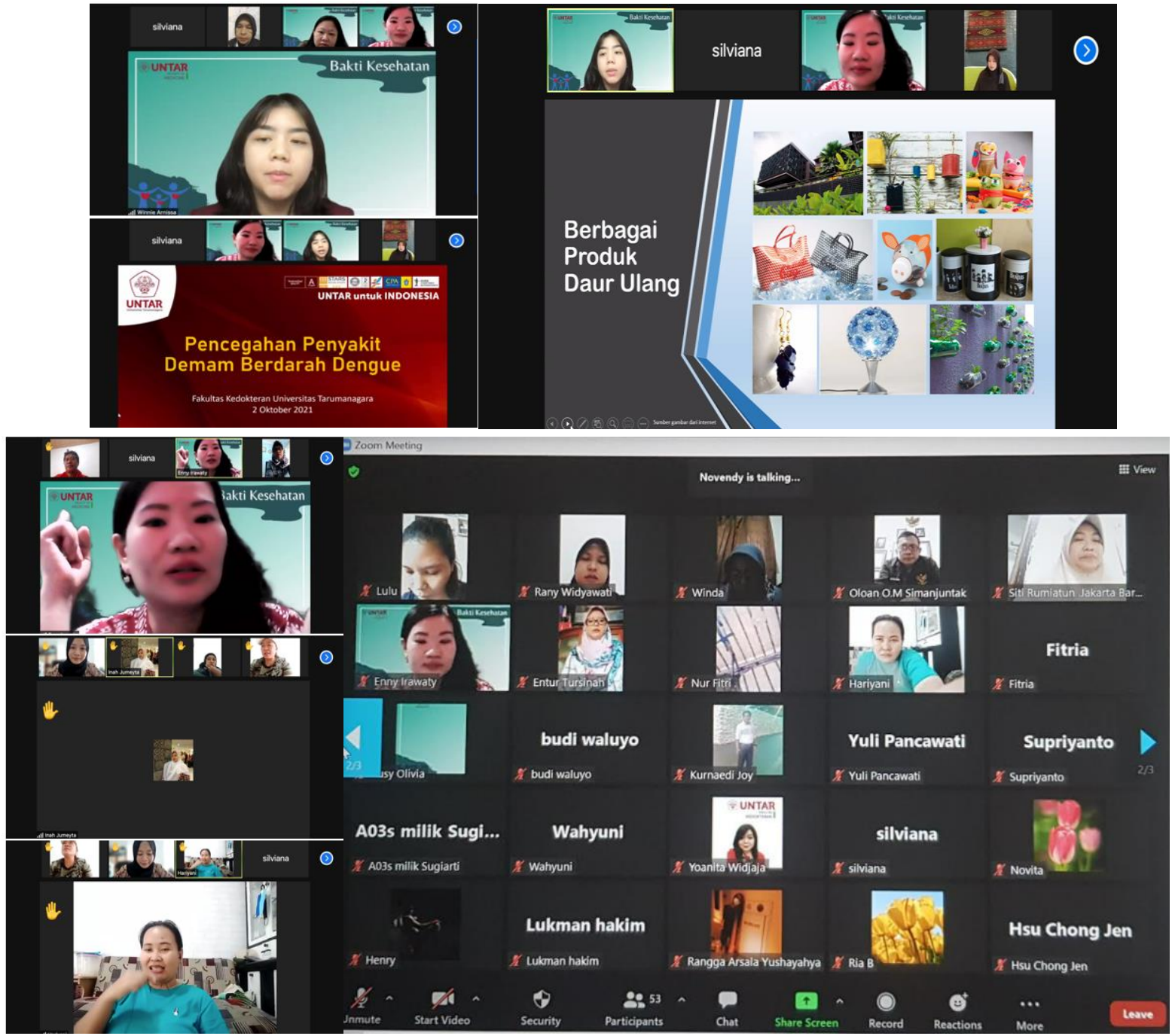

Gambar 3. Kegiatan Penyuluhan

Peserta mendengarkan materi yang disampaikan tim pengabdian sampai selesai. Kegiatan dilanjutkan dengan sesi tanya jawab secara langsung, dan salah satu peserta bertanya kepada tim pengabdian yaitu terkait pemberian abate pada air untuk membunuh jentik nyamuk, apakah air yang telah tercampur abate tersebut dapat diminum. Tim menjelaskan pemberian abate di air sesuai yang dianjurkan masih aman, jika mau diminum sebaiknya air dimasak dengan matang dan pemberian air minum yang tercampur abate tidak dianjurkan pemberiannya ke bayi atau anak. Sebelum kegiatan diakhiri maka peserta diminta untuk mengisi post-test. Semua peserta mengisi post-test yang diberikan tim pengabdian.

Untuk menilai apakah terjadi peningkatan pengetahuan pada peserta kegiatan penyuluhan "Cegah Demam Berdarah" maka tim pelaksana bakti kesehatan memakai nilai rata-rata pre-test dan post-test. Hasil tes awal para peserta didapatkan nilai rata-rata sebesar 67,65 dan hasil posttest rata-rata peserta yaitu 84,56 . Berdasarkan hasil dari nilai rata-rata pre-test ke nilai rata-rata post-test, dapat dilihat terjadi peningkatan pengetahuan pencegahan demam berdarah dengue $25 \%$. Hasil pre-test menunjukkan peserta mempunyai pengetahuan yang cukup baik terkait pencegahan, dan setelah mendengarkan materi yang disampaikan tim pengabdian, tingkat pengetahuan peserta semakin baik.

Penyuluhan tentang pencegahan kasus demam berdarah dengue efektif untuk meningkatkan pengetahuan dan bertambahnya tingkat pengetahuan berdampak pada sikap yang tepat untuk 
diterapkan dalam kehidupan sehari-hari guna mencegah seseorang terkena penyakit (Lontoh, RY, 2016). Edukasi kesehatan terkait pencegahan demam berdarah adalah bentuk tindakan promotif dan preventif yang ditanamkan di masyarakat sebagai upaya mencegah kesakitan karena demam berdarah dengue (Dawe, M., et.al, 2020). Seseorang yang terdiagnosis demam berdarah dengue membutuhkan waktu yang cukup lama dalam pengobatan serta pemulihan dan biaya yang besar sehingga kondisi ini harus dicegah (Kemenkes RI, 2011).

Kegiatan dalam penyuluhan kesehatan adalah salah satu bentuk edukasi di bidang kesehatan yang bermaksud memberikan informasi terkait materi penyuluhan serta informasi yang diterima oleh peserta dapat diterapkan dengan baik. Hasil umpan balik yang disampaikan peserta terkait materi serta penyampaian materi sudah baik dan peserta puas pada kegiatan penyuluhan ini karena materi mudah dimengerti dan menarik. Peserta ingin kegiatan tetap diadakan rutin karena menurut pendapat peserta saat ini sudah mulai masuk musim hujan serta kasus demam berdarah dengue pada musim hujan di wilayah Tomang Jakarta Barat meningkat.

Selain peningkatan pengetahuan tentang pencegahan penyakit demam berdarah dengue, tim pengabdian juga mengharapkan perubahan perilaku yang positif dari peserta kegiatan dengan rutin mempraktikkan langkah pencegahan melalui gerakan pemberantasan sarang nyamuk $3 \mathrm{M}$ plus. Oleh karena itu, seminggu setelah kegiatan penyuluhan, tim pengabdian melakukan follow up ke peserta dengan menanyakan kegiatan pencegahan demam berdarah dengue yang telah dilakukan. Peserta kemudian mendokumentasikan kegiatan pemeriksaan jentik nyamuk sebagai salah satu gerakan $3 \mathrm{M}$ plus. Para peserta kegiatan juga diharapkan menjadi kader jumantik yang aktif mempromosikan pencegahan penyakit demam berdarah dengue sehingga kasus demam berdarah dengue di wilayah Tomang Jakarta Barat dapat menurun.
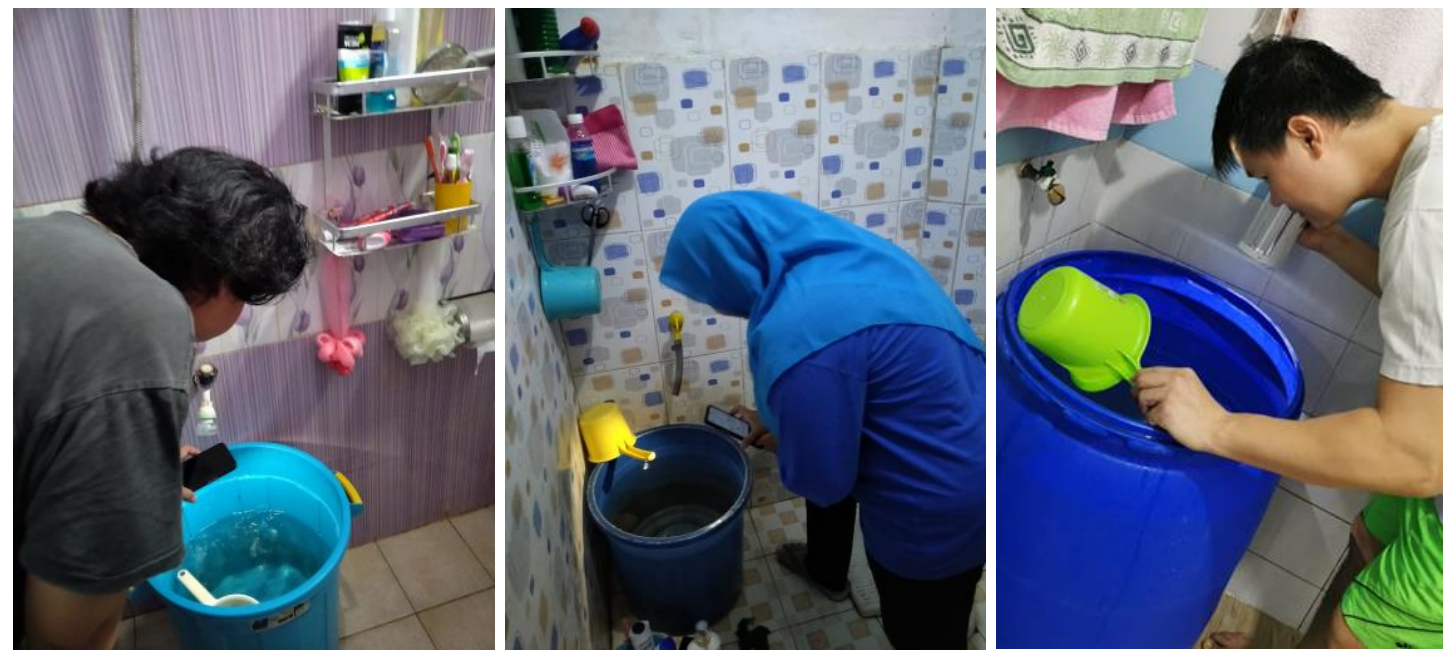

Gambar 4. Peserta Penyuluhan Melakukan Pemeriksaan Jentik Nyamuk 


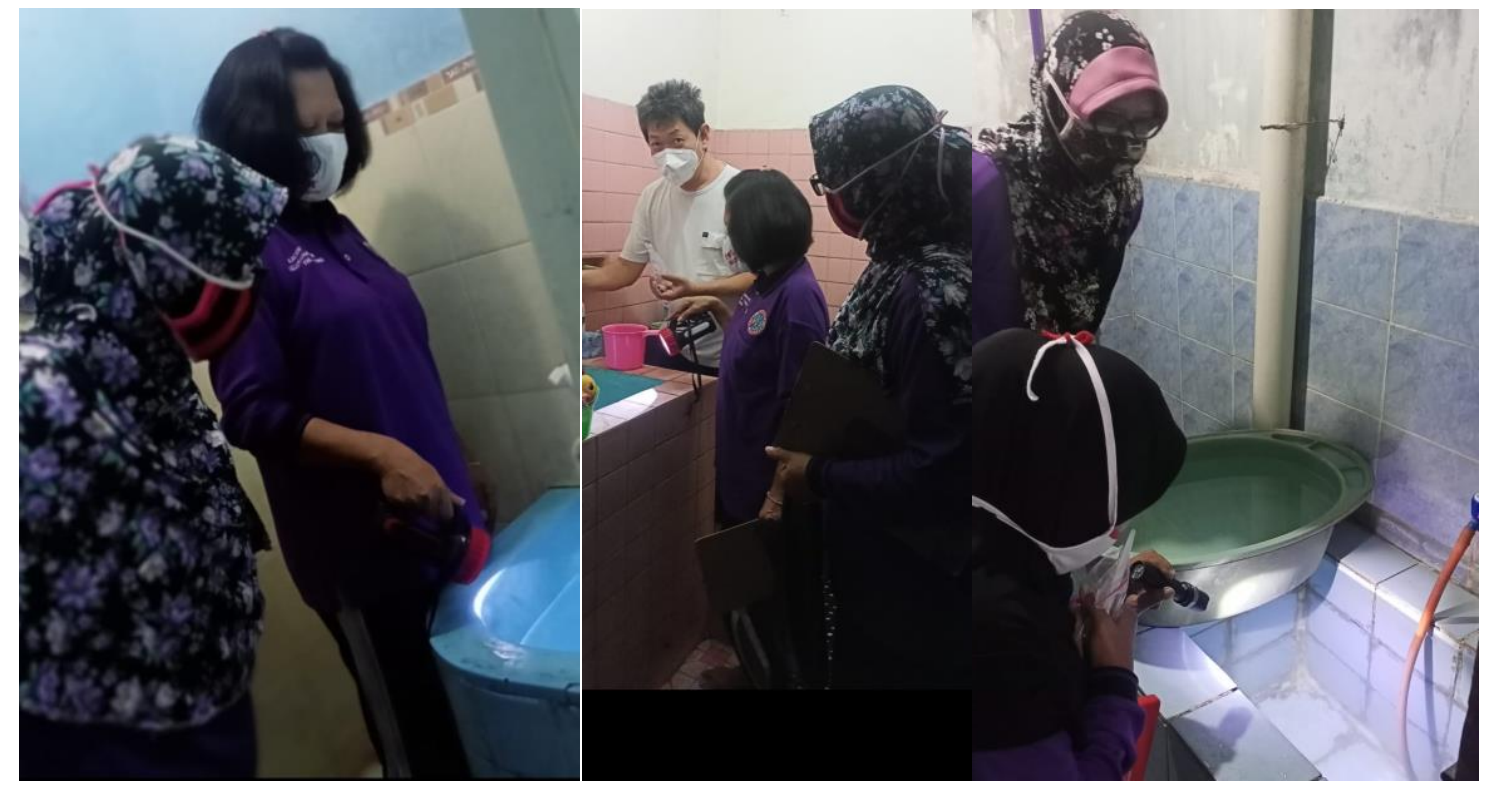

Gambar 5. Peserta Penyuluhan Sebagai Kader Jumantik

\section{KESIMPULAN DAN SARAN}

Kegiatan edukasi kesehatan yang diselenggarakan tim pengabdian FK UNTAR dengan tema "Cegah Demam Berdarah" pada tanggal 2 Oktober 2021 pukul 13.00-14.00 WIB diikuti 34 peserta dari wilayah Tomang Jakarta Barat. Peserta mendengarkan materi yang disampaikan tim pengabdian sampai selesai. Hasil tes awal para peserta didapatkan nilai rata-rata sebesar 67,65 dan hasil post-test didapatkan nilai rata-rata peserta sebesar 84,56. Hasil pre-test menunjukkan peserta mempunyai pengetahuan yang cukup baik terkait pencegahan demam berdarah dengue, dan setelah penyampaian materi edukasi oleh tim pengabdian, tingkat pengetahuan peserta semakin baik, dengan peningkatan pengetahuan sebesar $25 \%$. Umpan balik yang disampaikan peserta terkait materi serta penyampaian materi sudah baik dan mereka puas pada kegiatan penyuluhan ini. Tim pengabdian mengharapkan peningkatan pengetahuan diikuti dengan perubahan sikap dan perilaku yang positif terkait pencegahan penyakit demam berdarah dengue. Para peserta diharapkan rutin melakukan $3 \mathrm{M}$ plus sebagai cara pencegahan demam berdarah dengue sehingga kasus demam berdarah dengue dapat menurun di wilayah Tomang Jakarta Barat.

\section{Ucapan Terima Kasih (Acknowledgement)}

Penulis PKM mengucapkan terima kasih kepada Rektor Universitas Tarumanagara beserta jajaran, Lembaga Penelitian dan Pengabdian Masyarakat Univeristas Tarumanagara atas pendanaan sehingga kegiatan pengabdian kepada masyarakat dapat terlaksana. Terima kasih kami sampaikan kepada Pimpinan Fakultas Kedokteran Universitas Tarumanagara beserta jajaran atas dukungannya dalam pelaksanaan kegiatan PKM ini. Terima kasih kepada peserta PKM atas dukungan dan partisipasinya dalam kegiatan ini dan panitia SENAPENMAS yang memberikan kesempatan pada kegiatan SENAPENMAS 2021. 


\section{REFERENSI}

Dawe, M., Romeo, P., \& Ndoen, E. (2020). Pengetahuan dan Sikap Masyarakat serta Peran Petugas Kesehatan Terkait Pencegahan Demam Berdarah Dengue (DBD). Journal of Health and Behavioral Science, 2(2), 138-147. https://doi.org/10.35508/jhbs.v2i2.2283.

Husni, J., \& Rahmayanti, Y. (2018). Studi Kasus Demam Berdarah Dengue (DBD) terhadap Keberadaan Vektor Aedes Aegypti di Gampong Ateuk Pahlawan Kota Banda Aceh. SEL Jurnal Penelitian Kesehatan, 5(1), 26-35. https://ejournal2.litbang.kemkes.go.id/index.php/sel/article/view/1483

Karyanti, M. R., \& Hadinegoro, S. R. (2009). Perubahan Epidemiologi Demam Berdarah Dengue Di Indonesia. Sari Pediatri, 10(6). https://saripediatri.org/index.php/saripediatri/article/view/635

Kemenkes RI. (2018). Situasi Penyakit Demam Berdarah di Indonesia Tahun 2017. https://www.kemkes.go.id/article/view/19011500007/situasi-penyakit-demam-berdarahdi-indonesia-tahun-2017.html

Kemenkes. (2021).Hingga Juli, Kasus Dbd Di Indonesia Capai 71 Ribu. https://www.kemkes.go.id/article/view/20070900004/hingga-juli-kasus-dbd-di-indonesiacapai- 71-ribu.html

Kemenkes RI. (2017). Profil kesehatan Indonesia. Jakarta : Kemenkes RI. Diakses dari http://www.kemenkes.go.id

Kemenkes, RI. (2011). Informasi Umum Demam Berdarah Dengue, Jakarta: Kemenkes RI Ditjen PP dan PL. https://pusdatin.kemkes.go.id/download.php?file=download/pusdatin/buletin/buletindbd.pdf

Lontoh, R Y. (2016). Hubungan Antara Pengetahuan Dan Sikap Dengan Tindakan Pencegahan Demam Berdarah Dengue (DBD) Di Kelurahan Malalayang 2 Lingkungan III. PHARMACON Jurnal Ilmiah Farmasi - UNSRAT Vol. 5 No. 1 FEBRUARI 2016 ISSN 2302 - 2493. https://ejournal.unsrat.ac.id/index.php/pharmacon/article/view/11382 